\title{
バフ研磨の基礎と最新動向 ーバフ研磨の工具と装置一
}

\author{
安 部 賢 一*
}

*(株光陽社( $=969-0307$ 福島県白河市大信中新城塩沢 1)

\section{The Basics of Buffing Process and the Latest Trend - Tools and Machines for Buffing-}

\author{
Kenichi ABE*
}

*Koyo-sha Co., Ltd. (1, Shiozawa, Nakashinjyo, Taishin, Shirakawa-shi, Fukushima 969-0307)

Keywords : Buffing Process, Buffing Compounds, Hand Operated Machines, Automatic Machines

\section{1.はじめに}

バフ研磨による光沢仕上げ法は，剛性の高い研削砥石によ る鏡面加工とは異なり, 弾性的な接触下において物理的研磨 効果と同時に熱的または化学的な要因が複雑に作用して独特 の光沢面を生じさせるものである。その研磨方法, 研磨工具 などは，ここ 10 年大きな変化は見られていない。研磨加工 される製品としては, ステンレス鋼製品が最も多く, 研磨仕 上げの種類も多くなっている。その他の鉄鋼, アルミニウム 合金，銅合金などの材質の製品では，主にめっき，アルマイ トまたは塗装の前処理としての研磨が多い。めっき面の前処 理, 後処理としての研磨においては, 従来の光沢化を目的と した研磨は少なくなり，より機能的またはデザイン的な研磨 目の加工が要求されている。本稿では, バフ研磨の基礎的事 項として, 研磨用工具の種類, 使用方法および装置などにつ いて解説する。

\section{2. バフ研磨の方法}

バフ研磨は，円盤状の布を高速に回転させ，その外周面に バフ研磨剤を塗布することによって研磨を行う方法である。 図 1 にバフの形状 $(\mathrm{a}$ ：バイアス綿バフ, b : ユニットサイザ ルバフ)を示す。バフの構成材料であるサイザル麻または綿 布などに研磨能力はなく，バフ研磨剂を塗布することで初め て研磨作用を生じるものである。各種材質の光沢仕上げを行 う方法として最も能率的といえる加工法であり, 特有の研磨 作用から装飾的な光沢仕上げのみでなく，耐食性または摺動 性などの機能を与える平滑化加工法としても行われている。

$\dagger$ この解説は，「表面技術」誌，第 53 巻 (2002 年)，p. 41-46 に 掲載した内容をもとに図および写真の追加を含めて, 加筆・ 修正していただいたものです。

\section{1 研磨工程の分類}

バフ研磨における研磨工程は，一般的に次のような 3 段階 に分類できる (表 1 参照)。各工程の技術用語は, 確定した呼 称がないことから，慣用的に使われている呼称を示した。

(1) 粗研磨 (磨き, Polishing)

機械加工面, 圧延肌または細かな傷取りなどの素地調整を 行う工程である。この工程での研磨製品としては，一般機械 部品では $3 \mu \mathrm{mRz}$ 以下の仕上げ，鉄鋼材料のめっき加工製

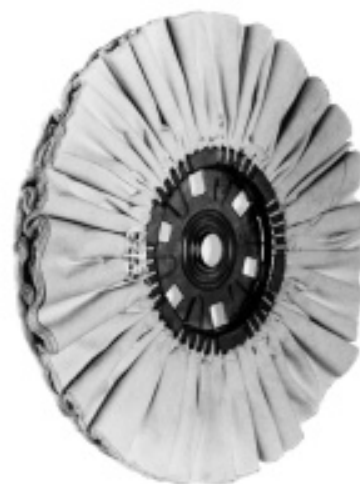

a) バイアス綿バフ

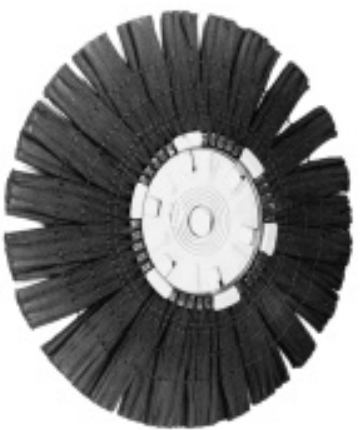

b）ユニットサイザルバフ
図 1 バフの形状

表 1 バフ研磨工程のバフ/研磨剤と仕上面(加工物：SUS 304)

\begin{tabular}{|c|c|c|c|}
\hline 研磨工程 & 研 磨 工 具 & $\begin{array}{c}\text { 表面粗さ } \\
\mathrm{R} z \mu \mathrm{m}\end{array}$ & $\begin{array}{l}\text { 光沢度 } \\
\text { Gs } 60^{\circ}\end{array}$ \\
\hline \multirow{2}{*}{$\begin{array}{l}\text { 粗研磨 } \\
\text { (磨き) }\end{array}$} & $\mathrm{KF}$ ホイール\# 400/トリポリ $\mathrm{K}-1$ & $1.0 \sim 3.0$ & $30 \sim 40$ \\
\hline & サイザルバフ/サイザー 46 & $0.5 \sim 0.8$ & $45 \sim 48$ \\
\hline \multirow{2}{*}{$\begin{array}{c}\text { 中研磨 } \\
\text { (磨き仕上げ) }\end{array}$} & サイザルバフ/プリンスライム & $0.3 \sim 0.5$ & $48 \sim 50$ \\
\hline & 綿バフ/M-343 & $0.2 \sim 0.4$ & $51 \sim 54$ \\
\hline \multirow{2}{*}{$\begin{array}{c}\text { 仕上げ研磨 } \\
\text { (仕上げ) }\end{array}$} & 綿バフ/アロックス & $0.05 \sim 0.1$ & $56 \sim 60$ \\
\hline & 綿バフ/青棒 $\mathrm{K}-1$ & $0.08 \sim 0.1$ & $54 \sim 60$ \\
\hline
\end{tabular}


品では $1 \sim 2 \mu \mathrm{mRz}$ 程度の研磨仕上げが行われる。研磨布 紙工具またはエメリーバフなどの細粒度を使用する場合には, トリポリなどの研磨剤で目つぶしを行うのが良い。サイザル バフを使用する場合には, 比較的剛性の高い研磨能力のある バフを使用する。中研磨につなげるには, 表面粗さを 2 $\mu \mathrm{mRz}$ 以下に研磨仕上げするのが適当である。

（2）中研磨(磨き仕上げ, Cutting down)

サイザルバフまたは綿バフによって, 粗研磨の加工面を整 える工程である。バフとしては, 中間的な剛性のバフを使用 し, 表面粗さを $0.3 \sim 0.6 \mu \mathrm{mRz}$ の半光沢面に研磨する。一 般的に，ステンレス鋼または鉄鋼材料などではサイザルバフ で，黄銅またはアルミニウム合金などでは綿バフで研磨する。 この工程で, 研磨の最終仕上げとする製品は多くあり, 一般 的なめっき加工製品, ステンレス鋼の仕上げでは\# 400 仕上 げ(No. 6 仕上げ)製品などがある。

（3）仕上げ研磨(仕上げ, Coloring)

軟らかな綿バフによって, 表面粗さ $0.1 \mu \mathrm{mRz}$ 程度の光沢 面を得る工程である。バフ研磨剤は, 製品材質または仕上げ 品質によって酸化クロム系, アルミナ系または酸化鉄系の研 磨剤を選択する。仕上げ面は, 表面粗さ $0.05 \sim 0.2 \mu \mathrm{mRz}$ の 範囲であり，準鏡面または鏡面仕上げなどと呼ばれ，ステン レス鋼の\# 600 仕上げ(No. 7 仕上げ), \# 800 仕上げ(No. 8 仕 上げ) または貴金属めっき加工製品などである。その表面粗 さの範囲は狭いが, 光沢 (つや)の質感, バフ傷の微妙な差な どが評価されるため, バフの材質, 研磨剤の種類および研磨 条件などのきめ細かな選定が必要である。

\section{2 研磨方法}

研磨による仕上げとは, 研磨加工によって得られる製品の 光沢，つやの色または研磨目の方向性などをパターン化，デ ザイン化することで製品価值を付加している仕上げ方法であ る。しかし, この意匠には単にデザイン的な要求だけでなく, つや消し仕上げの防眩性, つや出し仕上げの污れ防止などの 機能的な意味合いも含んでいる。研磨仕上げの種類としては, 表 2 に示すような方法が行われている。

装飾めつきおよび硬質クロムめつきにおける研磨の傾向は 次のとおりである。ニッケルめっき, クロムめっきまたは貴 金属めつきなどの装飾めっきでは, めっきのレベリング性お よび光沢化が向上しており, 従来の銅めっき後の仕上げのよ うな平滑化または光沢化を目的とした研磨は，ほとんど行わ れていない。主に行われている研磨は, めっき前の素地調整 を目的とした研磨である。

めっき面の研磨としては, 銅めっき面またはニッケルめっ

表 2 研磨仕上げの種類と研磨工具

\begin{tabular}{|c|c|c|}
\hline \multicolumn{2}{|r|}{ 仕上げの種類 } & 研磨工具 \\
\hline \multirow{3}{*}{$\begin{array}{c}\text { 艶 } \\
\text { 消 } \\
\text { 乙 }\end{array}$} & サテン仕上げ & 研磨ベルト \\
\hline & ヘアーライン仕上げ & 研磨布ホイール \\
\hline & クロスハッチ仕上げ & 不織布ホイール \\
\hline \multirow{3}{*}{$\begin{array}{l}\text { 艶 } \\
\text { 出 } \\
\text { 乙 }\end{array}$} & 半光沢仕上げ & サイザルバフ \\
\hline & & \\
\hline & 光沢仕上げ & $\begin{array}{l}\text { 綿バフ } \\
\text { 什上用バフ研磨剂 }\end{array}$ \\
\hline
\end{tabular}

き面のへアーライン仕上げ，サテン仕上げなどがあり, 研磨 不織布のホイールまたはバフなどで研磨仕上げされている。 このようなめっき面では, めっき層が薄いことから軽く押し 付けて研磨目を入れる研磨方法である。特に, 樹脂めっき製 品では, 研磨熱によってめっき層のフクレ, 剥がれが生じ易 いため, 低周速度 $(500 \mathrm{~m} / \mathrm{min}$ 以下)で柔らかな研磨工具を 使用して軽く研磨するのが良い。

硬質クロムめっき面の研磨は, 摺動性, 耐食性を与える機 能性研磨として重要な加工である。一般的な鉄鋼材料よりは, 硬さが $\mathrm{Hv}=700 \sim 1000$ と硬いため, 研磨取り代が少なくな ると同時に, 研磨面粗さも鉄鋼材料の $1 / 2$ 程度となる。 めつき前の研磨において, 研削砥石または研磨ベルトなどの 研磨で研磨目が立っていると, こぶ状めっき, 密着性不良な どが生じることがある。このため，バフ研磨によって研磨目 を滑らかにすることが必要となる。

光沢仕上げ，摺動性を良くし平滑化を目的とするシリンダ ロッドや機械部品などの研磨では, 研磨ベルトまたは研磨不 織布ホイールの\# 400〜\# 800, さらにサイザルバフまたは綿 バフなどの研磨で表面粗さ $\mathrm{Rz}=0.3 \sim 0.8 \mu \mathrm{m}$ 程度に仕上げ られる。また高い寸法精度, 平滑度を要求される各種ロール 類では, ロール研削盤またはバーチカル研磨機で弾性砥石\# 400〜\#1500を使用して鏡面加工される。この研磨後に, 圧 延用または印刷用などの用途によって表面粗さを調整する研 磨を行うことがある。この研磨には, 研削砥石, 研磨ベルト, 研磨不織布ホイール, サイザルバフまたは綿バフなどの各種 研磨工具が，目的の表面状態に応じて使用される。

\section{3. 研磨工具}

\section{1 バフの種類}

バフの基材としては，サイザル麻または綿布などが一般的 であり, 研磨目的に応じて選択される。表 3 にバフの種類と 用途を示す。布の硬さは，糸の打込み本数の多いほど硬くな り, バフの腰が強くなることで研磨能力が高くなる。このた め, 研磨工程におけるバフ基材の選定としては, 打込み本数 の多いものは粗研磨または中研磨に使用し, 打込み本数の少 ないものは仕上げ研磨に使用する。サイザル麻は, その繊維剛 性の高さから, 綿布を使用したバフでは得られない高い研磨 能力があり, 研磨工程の省力化には非常に効果的である。図

表 3 バフの種類と用途

\begin{tabular}{|c|c|}
\hline バフの種類 & 用 \\
\hline バラ綿バフ & 仕上げ用, M の方が腰が強い \\
\hline 渦巻綿バフ & 中・仕上げ用, 腰が硬く器物研磨に向く \\
\hline バイアス綿バフ $\mathrm{M}-0 \sim \mathrm{M}-8$ & 中・仕上げ用, 最も沉用的な綿バフ \\
\hline オープン綿バフ & 仕上げ用, バイアス綿より当り柔らかい \\
\hline バイアスネルバフ & 仕上げ用，合成樹脂および貴金属に適する \\
\hline プリーツ綿バフ & 中・仕上げ用, バフ面平滑で切れ味ある \\
\hline ジスクサイザルバフ & 粗・中研磨用, 器物研磨に向く \\
\hline オープンサイザルバフ & 粗・中研磨用, なじみ大, 広幅研磨に適 \\
\hline ワイドフィンガーサイザルバフ & 粗・中研磨用, オープンより腰が強い \\
\hline ユニットコードサイザルバフ & 粗研磨用, 高負荷に向き切れ味がある \\
\hline
\end{tabular}


2 にバイアスバフの糸の方向(織り方向)の例を示す。

(1) バラ綿バフ

円形に打ち抜いた綿布の織り方向を変え, 適当枚数を重ね 合わせて中心部のみを縫ったバフである。当たりが軟らかく， 研磨目の均一性に優れることから各種金属, 合成樹脂などの 仕上げ研磨用として最も一般的なバフである。仕上げの程度 によって, 青厚, $\mathrm{M}$ 生地, $\mathrm{C}$ 生地, キャラコ, ブロードま たはカナキンなどの基材種類を選択する。

(2) 渦巻綿バフ

円形に打ち抜いた綿布または古布の端切れなどの織り方向 を変え, 適当枚数を重ね合わせて同心円状または渦巻き状な どにミシン掛けを行ったバフである。ミシン縫い目の間隔に よってバフの硬さを変えることができ, 研磨時のなじみ性, 仕上げ程度によって調節する。剛性の高いバフであり, 高荷 重または狭い幅部分の研磨などに中研磨用, 鉄バフ用として 使用される。

(3) バイアス綿バフ

バイアスカットされた基材を多数のヒダがつくように絞り 込み，基材のたて糸，よこ糸方向がバフ外周面に対して $45^{\circ}$ になるように中心を金具で固定したバフである。バフ外周面 がバイアス状のため, 布のほつれが少なく, バラ綿バフに比 べて 1.5 倍以上のバフ寿命があり, 研磨特性が安定している ことから, 手磨き, 自動研磨での粗研磨から仕上げ研磨まで 広範囲のバフ研磨に適用できる。

ヒダの数が多いほど剛性が高くなり, バラ綿バフ相当の軟 らかさから，渦巻き綿バフ相当の硬さまでを M- $0 ， 2 ， 4$, 6,8 の 5 段階に等級化されている。研磨工程での選択とし ては, 粗研磨, 中研磨には M- 4 から M-8 を, 仕上げ研磨 には M- 0 から M- 2 が使用される。

(4) ディスクサイザルバフ

円形に打ち抜いた綿布とサイザル麻を組み合わせて, 渦巻 き状にミシン縫いしたバフである。サイザル麻を綿布と組み 合わせることによって, サイザル麻のほつれを防ぐと同時に 研磨剤の保持能力を高めている。バフの幅が狭く剛性の大き いことから，小物部品，狭い幅部分などの粗研磨，中研磨に 適している。

（5）オープンサイザルバフ

バイアスカットされたサイザル麻を綿布の間に挟み込んだ 基布を，絞り込んで金具に固定したバフである。バフ表面に は, ゆるやかなヒダが付き適度な柔軟性があり, 広幅研磨で の均一な研磨面と異形面へのなじみ性を持った最も汎用的な
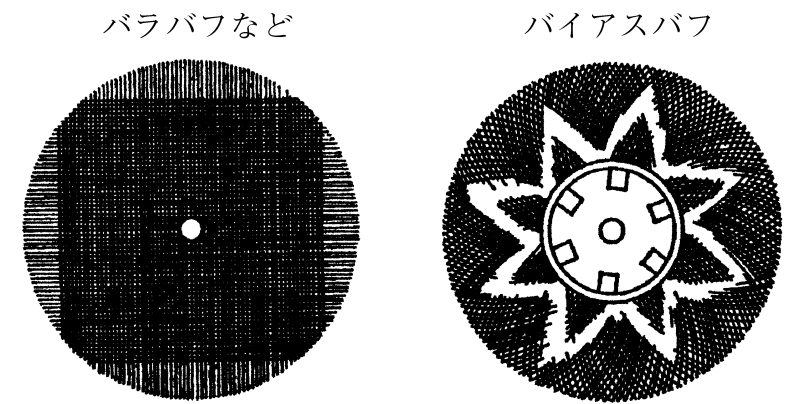

図 2 バイアスバフの糸の方向
サイザルバフである。

（6）ワイドフィンガーサイザルバフ

バイアスカットされたサイザル麻を綿布の間に挟み込んだ 基布を，ゆるやかなプリーツ状に成形し，絞り込んで金具に 固定し，適当間隔にミシン縫いしたバフである。バフ表面は， 比較的平坦で密に作用し, 研磨時の当りの均一性と適度の剛 性があり，鉄またはステンレス鋼などの粗研磨から中研磨に 適している。

（7）ユニットサイザルバフ

バイアスカットされたサイザル麻を綿布で包み込み，細長 く折りたたみミシン掛けを行ったユニットを, 保持金具に放 射状に固定したバフである。比較的剛性の高いバフであり, 鉄鋼または非鉄金属の粗研磨，めつき前の中研磨などに使用 される。高い研磨圧力によって, 緩やかな 3 次元曲面へのな じみ性があることから, 鉄またはステンレス鋼のプレス成形 品などの異形品の粗研磨, 中研磨に適している。

サイザル麻コード(撚りひも)をユニットとしたバフは，ユ ニットコードサイザルバフであり, より剛性の高いバフであ る。特に, ブラック処理を行ったバフは, 剛性が非常に高く なり, 研磨剤の保持性能も良好で, 非常に高い研磨効果と寿 命がある。鉄，ステンレス鋼などの粗研磨に適しており，曲 面のある加工物を高い押付荷重で研磨するには最適である。

\section{2 バフの処理}

バフ処理は，バフに樹脂または油脂などを含浸処理するこ とによって, 研磨時の寿命, なじみ性または研磨剤の保持性 能などの研磨特性を加工条件に適するように調整するもので ある。特に, サイザルバフでは, 未処理バフの欠点として繊 維のほつれ, 脱落が多く生じることから, 処理をすることに よって耐久性および研磨剤の保持性能の向上が得られる。バ フ処理には，以下のような効果がある。

(1)繊維を強化し，織物のほつれを防ぐ

(2)バフの腰の強さを調節する

(3)バフ研磨剤の付着性, 保持性能を良くする

\section{3 ブラシ}

研磨ブラシは，金属線または非金属線を放射状に固定した， 柔軟性のある工具である。研磨ブラシは，高速回転をすると 当りが硬くなるので, 適度な回転数で使用することによって, 複雑形状な製品のばり取り, $\mathrm{R}$ 付けまたはクリーニングに効 果的な研磨工具である。粗研磨には金属線を, 中研磨には研 磨材入り化学繊維を, 仕上げ研磨には動物の毛または植物繊 維を使用するのが一般的である。金属線での粗研磨では，ブ ラシ線材を樹脂で固めて，剛性を高めることおよび線材の曲 がりを防止することで粗研磨の研削効果を高めている。

\section{4 研磨不織布}

ナイロン繊維不織布に砥粒を固着させた工具であり，不織 布の柔軟性と砥粒が 3 次元的に分布していることに特徴があ る。研磨布工具とバフの中間的な研磨特性となる。研磨材は, アルミナ系と炭化ケイ素系が使用されており, その製品の粒 度表示は研磨布のような粒度呼称ではなく, 細目または $\mathrm{F}$ (Fine)などとする表示が一般的に行われている。

ばり取り, つや消し, ヘアーライン, めつき処理前後の研 磨またはクリーニングなどに使用される。研磨時の条件とし 
ては，基材の耐熱性から研磨布製品より低周速度の $1500 \mathrm{~m} /$ min $2000 \mathrm{~m} / \mathrm{min}$ 程度で使用する。工具形状としては, 研 磨布工具と同様に次のような各種の構造 (図 3 ) がある。

(1) バフタイプ

研磨不織布をゆるやかなヒダが付くように絞り込んで中心 を金具で固定したバフ状のホイールである。軽研磨でのつや 消し仕上げに使われる。

(2) $\mathrm{PH}$ タイプ

研磨不織布ディスクを複数枚積層し, 圧力をかけて押し固 めたホイールである。積層密度によって, 弾力性のあるホ イールから砥石に近い剛性のホイールまで製造でき, 研磨不 織布ホイールとして最も切れ味のあるホイールである。

(3) KF タイプ

研磨不織布片を，パイプ芯に放射状に固定したフラップホ イールである。当たりが柔らかく, なじみ性があり軽研磨で のつや消し仕上げ，ヘアーライン仕上げに使われる。

(4) RA タイプ

研磨不織布を, パイプ芯に強く巻き付け成形したホイール である。剛性の高いホイールで, 工具寿命が長く汎用的な研 磨仕上げに使用される。特に, グリース含浸ホイールは, 寿 命が長くなると同時にサイザルバフ研磨に近い仕上げが得ら れる特徴がある。

\section{5 研磨フィルム}

ポリエステルフィルム上に, $0.2 \sim 16 \mu \mathrm{m}$ 程度の研磨材を 塗布した研磨布で, ラッピングフィルム, ラッピングテープ または研磨テープなどとも呼ばれるものである。作業性の良 さ, 加工物の污れが少ない, 自動化し易いなどの特性から, 従来遊離砥粒によるラッピングを行っていた加工に, 精密仕 上げ用工具として使用されている。研磨布と比較すると, 以 下のような特徵がある11。

(1)基材フィルムの厚さが均一であり, 均一な仕上げ面が安 定して得られる。

(2)基材厚みは $25 \sim 100 \mu \mathrm{m}$ 程度であるが，厚みで比較する と研磨布より強度は強い。

(3)基本的に砥粒が脱落しないように作られており, 単一層 の研磨材層で研磨を行う。

使用方法としては, 研磨フィルム面に切粉が付着すると研 磨傷が生じるため, 研磨フィルムを順次低速で送り出すか, または間欠的に送り出して, 常に研磨フィルム新生面での加

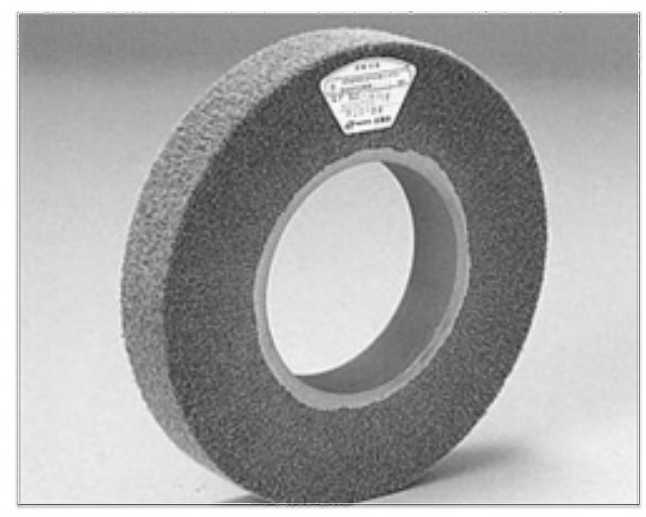

図 3 研磨不織布の一例
工を行うようにする。研磨方法は, 研磨布加工と同様なテン ション方式(フリーベルト方式), バックアップ方式(プラテ ン方式)などがある。

\section{6 バフ研磨剤}

バフ研磨剤は, 油脂類 (動物性, 植物性および鉱物性など) と各種研磨材 (アルミナ, 酸化クロムまたはけい石など)を適 度に配合し，かく汼混合した研磨用組成物である。金属用， 非鉄金属用, 貴金属用および合成樹脂用などがあり, 各種材 質の粗磨きから仕上げ研磨に対応する製品がある。バフ研磨 剤の種類は, 固形バフ研磨剤と液状バフ研磨剤に分類されて いるが，一般的にバフ研磨剤と称すると固形バフ研磨剤を指 している。表 4 にバフ研磨剤の種類と用途を示す。

バフ研磨剤では, 油脂類と研磨材の混合比率を研磨目的に 合わせ油脂類 20〜30\% 程度としている。この油脂類の性質 と配合量は, バフ研磨に大きな影響を与えており, 以下のよ うな効果および作用がある。

(1)研磨材をバフ面に付着させ，飛散を防止する。

(2)潤滑作用，焼け防止作用がある。

(3)研磨能力, 光沢のバランス作用がある。

(1) 固形バフ研磨剤

脂肪酸，硬化油または松脂などを適当に配合し，研磨材と 練り合わせて成形した固形棒状のバフ研磨剤(図 4 )である。 研磨目的に応じて, 研磨特性の微調整ができ, 多種類のバフ 研磨剤がある。最も広い用途に使用されているのは，焼成ア ルミナを使用した白棒, ライム系のバフ研磨剤であり, 粗研 磨から仕上げ研磨までのほとんどの研磨に対応できる。塗布 方法は, 作業者がバフ研磨剤を手にもってバフ表面に塗りつ ける手塗りが一般的である。機械的な塗布方法としては, 固

表 4 バフ研磨剤の種類と用途

\begin{tabular}{|c|c|c|c|c|}
\hline 研磨 剂 & 研磨材 & 研磨工程 & バフ材質 & 用 \\
\hline サイザー & \begin{tabular}{|l|} 
溶融アルミナ \\
燒成アルミナ
\end{tabular} & 粗研磨 & サイザル & $\begin{array}{l}\text { 炭素鋼 } \\
\text { ステンレス鋼 }\end{array}$ \\
\hline ライム & 焼成アルミナ & $\begin{array}{c}\text { 中研磨 } \\
\text { 仕上げ研磨 }\end{array}$ & $\begin{array}{l}\text { サイザル } \\
\quad \text { 綿 }\end{array}$ & $\begin{array}{l}\text { 炭素鋼, ステンレス鋼 } \\
\text { 黄銅, アルミニウム }\end{array}$ \\
\hline トリポリ & けい石 & 中研磨 & $\begin{array}{l}\text { サイザル } \\
\quad \text { 綿 }\end{array}$ & $\begin{array}{l}\text { 黄銅, ダイカスト } \\
\text { アルミニウム, 樹脂 }\end{array}$ \\
\hline 赤 & 酸化鉄(微紛) & 仕上げ研磨 & キャラコ & 金, 銀, 白金 \\
\hline 青 棒 & \begin{tabular}{|l|} 
三酸化二クロム \\
(酸化クロム)
\end{tabular} & 仕上げ研磨 & 綿 & $\begin{array}{l}\text { ステンレス鋼, 黄銅 } \\
\text { 硬質クロムめつき }\end{array}$ \\
\hline ダンジー & 非晶質シリカ & 仕上げ研磨 & 綿 & 合成樹脂, 塗装面 \\
\hline
\end{tabular}

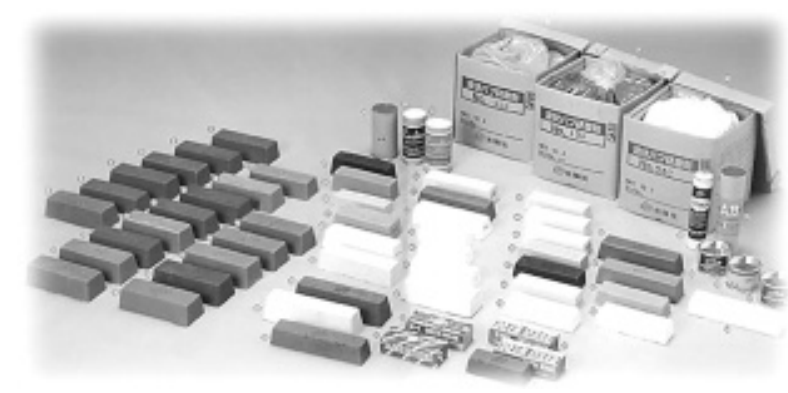

図 4 バフ研磨剤 
形アプリケータと呼ばれる固形バフ研磨剤自動塗布装置があ る。

（2）液状バフ研磨剤

液状バフ研磨剤は, 固形バフ研磨剂と同様の研磨材, 油脂 類を水と混合し，エマルジョン化させた高粘度の液体状バフ 研磨剤である。スプレーガンでの噴射塗布が可能なため, 主 に自動研磨機用バフ研磨剤として使用されている。切れ味ま たは光沢などの研磨能力は, 水分を含むことから固形バフ研 磨剂よりわずかに低下する傾向がある。塗布方法としては, エアスプレ，エアレススプレまたはスプレーガン内増圧スプ レなどでバフ表面に噴射塗布するのが一般的である。塗装板 の研磨では, 液状バフ研磨剤を水で希釈し，八ケ塗りまたは ロールコートなどで加工物に塗布する方法が用いられること がある。

\section{4. 研磨装置}

研磨される製品は, 機械部品, 自動車部品, 弱電機器, ア クセサリ類，大型タンクなど，形状，大きさなどさまざまで ある。研磨装置は, 製品の形状および研磨する部分から, 研 磨工具の当て方や製品の動かし方を決め，その動作を実現で きるような研磨機の構成を検討する。研磨機の種類としては, 第一に加工物の形状や大きさによって加工物を保持して研磨 するか, 研磨工具を保持して研磨するかを, 第二に生産量や 仕上げの均一性によって手磨きにするかまたは自動研磨にす るかを決める。表 5 に研磨機の種類と用途を示す。

\section{1 手磨き用研磨機}

(1) マイクログラインダ

小型グラインダを片手で保持して研磨する小型の研磨機で あり, 軸径 2.34 または $3.0 \mathrm{~mm}$, 外径 $6 \sim 30 \mathrm{~mm}$ 程度の軸 付き研磨工具を取り付けて 10000 30000 rpm の高速回転で 研磨を行う。用途としては, 金型, 義歯またはアクセサリ類 などの小物部品の仕上げ研磨に使用される。グラインダ先端 ヘッドを交換することによって，アングルグラインダとして 外径 10〜 $40 \mathrm{~mm}$ の軸付きパッドを取り付けて研磨をするこ ともできる。

（2）ディスクサンダ

ディスクサンダは，ディスク状研磨工具を使用する小型の

表 5 研磨機の種類と用途

\begin{tabular}{|c|c|c|}
\hline \multicolumn{2}{|r|}{ 研磨機の種類 } & 用 \\
\hline \multirow{6}{*}{$\begin{array}{l}\text { 手 } \\
\text { 磨 } \\
\text { 杯 } \\
\text { 機 }\end{array}$} & マイクログラインダ & 金型，指輪 \\
\hline & ディスクサンダ & 傷取り, 溶接部 \\
\hline & ポータブルサンダ & 樹脂板, 塗装面 \\
\hline & ポリッシャ & 樹脂板, 塗装面 \\
\hline & フレキシブルサンダ & タンク, 看板 \\
\hline & バフレース & 器物, 各種製品 \\
\hline \multirow{5}{*}{$\begin{array}{l}\text { 䚁 } \\
\text { 研 } \\
\text { 梀 } \\
\text { 機 }\end{array}$} & ロータリ形 & 器物, ドアノブ \\
\hline & ストレート形 & パネル, 洋食器 \\
\hline & 往復形 & 板, 形鋼 \\
\hline & センタレス形 & パイプ, シャフト \\
\hline & 研磨ロボット & 水栓金具, バンパ \\
\hline
\end{tabular}

ポータブル研磨機で電気式と空気式がある。溶接部の研磨, 鋳物の研磨，錆落しまたは傷除去などに使用される。

電気式サンダは, サンダ重量は重いが, トルクが強く作業 時の回転低下が少なく強力研磨に向いている。ただし, 引火 性材料を扱う作業場ではスパークによる引火の危険性がある。 空気式サンダは, サンダ重量が軽く片手作業も容易であるが, 作業時の回転数低下や空気絞り弁の調節加減などの作業性に 慣れが必要である。各サンダに使用する研磨工具の穴径は, 一般的には電気式が $\phi 15 \mathrm{~mm}$, 空気式が $\phi 16 \mathrm{~mm}$ となって いる。

（3）ポリッシャ

ポリッシャは, 樹脂や塗装面の素地調整または仕上げ研磨 に使用されるポータブル研磨機である。研磨工具の駆動軌跡 によって，回転運動のみのポリッシャ，前後に振動するスト レートサンダ，偏芯による細かな円運動をするオービダルサ ンダおよび偏芯によるオービダル円運動とパットの自転によ る回転運動を組み合わせたデュアルアクションサンダなどが ある。

仕上げ研磨では，デュアルサンダまたはポリッシャなどに 羊毛ボンネットバフまたはスポンジバフなどを取り付け，バ フ研磨剤を塗布して研磨を行う。ポリッシャは, 研磨工具の 回転運動で研磨するものであるが, ディスクサンダより低速 のものが使用される。

(4) フレキシブルサンダ

小型モータの回転をフレキシブルワイヤによってバフ研磨 軸に伝え, 外径 150〜250 mm の研磨工具を取り付けて, 回 転数 2000 3000 rpm で回転させて研磨を行う。研磨工具を 保持して研磨できるため, 大型タンク壁面, 看板などの大型 部品の研磨に使用される。

(5) バフレース

モータ直結型バフレースは，モータ軸シャフトが研磨軸と 一体化している構造である。構造, 保守が簡単で安価でもあ るが，モー夕容量に制限があるので強圧での研磨はできない。 卓上研磨機は, モー夕直結の単頭または両頭のモー夕容量 100 $300 \mathrm{~W}$ 程度の手磨き用小型研磨機である。研磨工具は, 外径 100〜200 mm 程度を使用し, 指輪, アクセサリ類また は各種小物部品などの研磨に使用される。

モータ内蔵型バフレースは，モータ軸の回転をプーリと $\mathrm{V}$ ベルトによって, 研磨軸に伝える構造である。研磨軸の 剛性，機械振動にも充分な配慮がされ，モー夕容量も用途に 応じて使い分けられる，最も一般的な手磨き用研磨機である。 最近は, 各種材料の研磨に適した回転数が容易に選択できる ような，インバータ変速のバフレースが使われている。

バフレースで使用する研磨工具は，一般的には外径 350 $\mathrm{mm}$ 程度であるが, 加工物形状によっては, より小さな外径 ( $\phi 30 \sim 100 \mathrm{~mm})$ の研磨工具を使用することがある。このよ うな場合には, いも芯, 三分芯などの替芯をバフレース研磨 軸先端に取り付けることによって, 小径の研磨工具での研磨 を行う。

\section{2 自動研磨機}

加工物の供給脱着装置および自動送り装置を備え, 複数の 研磨ヘッドによって加工物の研磨工程を自動化した研磨機で 
ある。加工物の形状，素地状態および仕上げ面などによって 研磨ベルト，KF ホイールまたはバフなどの研磨工具を目的 に応じ組み合せて使用する。研磨機の構造としては，一般的 に加工物がインデックステーブル上で回転運動するロータリ 形と, 加工物が直線送り運動するストレートライン形に大別 される。図 5 に送り方式による研磨機の構成を示す。

(1) 器物研磨機

自動研磨機としては，最も汎用性のある研磨機の形式であ り, 加工物形状や研磨目的に合わせた送り装置に複数の研磨 ヘッドを構成したものである。研磨ヘッドの台数は，研磨工 程数(通常 $2 \sim 4$ 工程) と製品形状による加工面分割数によっ て決定される。

ロータリ形は，設置面積はコンパクトであるが一般的に 10 ヘッド以下の構成であり, 研磨分割数の少ない比較的単 純形状の研磨に向いている(図 $\left.6^{3)}\right)$ 。研磨される製品は，ド アノブ，鍋または魔法瓶などの丸物製品の研磨が主である。 ストレートライン形(図 $7^{4}$ ) は, 設置面積は大きくなるが多 数台の研磨へッドを設ける構成が可能で，加工面分割数の多 い異形品または角物製品の研磨に向いている。研磨される製 品としては，パネル，バンパ，水栓金具または洋食器などが ある。

\section{(2) 板研磨機}

一定寸法に切断加工された板材を研磨する研磨機で, 加工 物幅が $500 〜 1500 \mathrm{~mm}$ と広幅の表面を均一に仕上げるバフ研 磨機が主である。研磨機の構成は，広幅の研磨ヘッドを 1 台

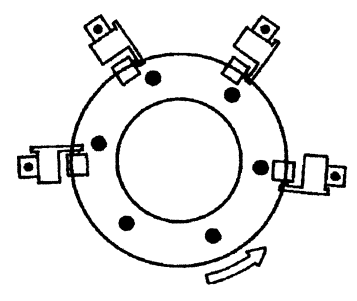

(a) ロータリ形

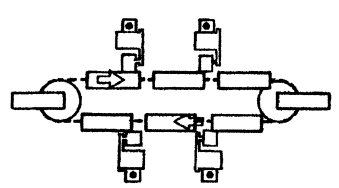

(b) ストレートライン形

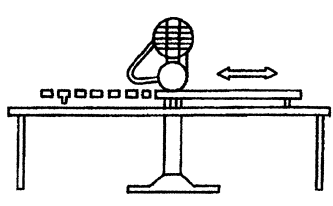

(c) 往復形
図 5 送り方式による研磨機の構成 2

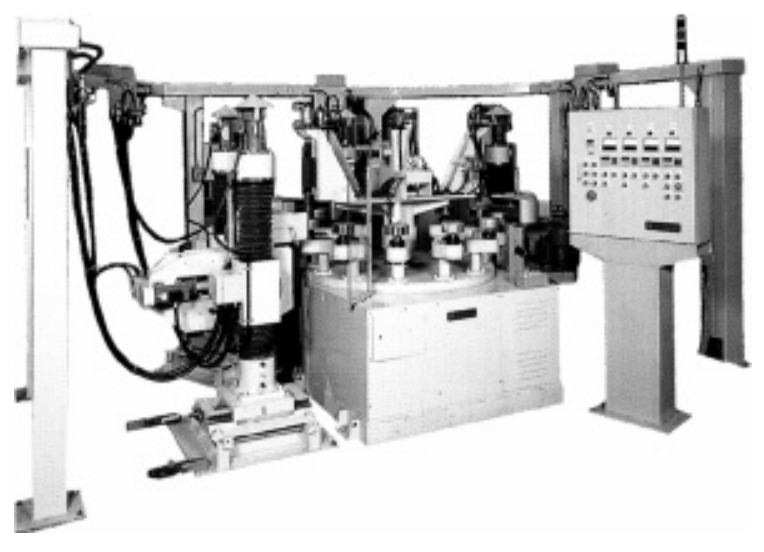

図 6 ロータリ形研磨機3)
設置し, 機械的チャックまたは真空チャックなどで加工物を 固定した送り装置を往復させて研磨を行うのが一般的である。 研磨製品としては，ステンレス鋼板，樹脂板などの建築用パ ネルや厨房用製品などである。ステンレス鋼 $2 \mathrm{~B}$ 材定尺板 の研磨では, \#400 仕上げ(サイザルバフ仕上げ), \#600 仕上 げ(綿バフ仕上げ)などが行われている。

最近の建築用ステンレス鋼鏡面板 (\# 800 仕上げ) は，バー チカルタイプの湿式研磨機を使用することで平滑性の高い鏡 面板の研磨を行っている。この研磨方法は, ステンレス鋼 2 $\mathrm{B}$ 材からの研磨では非常に多くの研磨工程が必要なため, BA 材からバフ研磨で鏡面仕上げをする方法も行われている。 （3）コイル研磨機

複数の研磨ヘッドを設置して, 長尺のコイル材を素材から 仕上げまでを一貫して研磨する研磨機である。一般的に，コ イル材送り速度が $10 \mathrm{~m} / \mathrm{min}$ 以上と高速度であり, 研磨効率 が低くなることから， 5 〜 10ヘッドと多数の研磨ヘッドを 必要とする。研磨効果を高めるために, 研磨工具の押付荷重 を高めるような研磨機剛性および加工物バックアップの方法 などの荷重方法が工夫されている。

ヘアーライン仕上げを行う時には，炭化ケイ素系研磨布 ロール\#120または\#150をコイルに押し付けながら, 研磨布を 間欠的または極低速で送り出し，ヘアーライン目を付けてい る。

（4）センターレス研磨機

センターレス研磨機は, 調整車に適度の角度を付けて加工 物を回転させて, 加工物に回転と横方向への送り力を与えて 研磨する方式である。丸棒の外周面を研磨する方式であり， 装飾用ステンレスパイプ，ゴルフシャフトまたはシリンダ ロッドなどの研磨に広く使用されている。

この研磨機では，パイプ長手方向と直角に研磨工具を押し 付けて加工を行う横目研磨が一般的であるが，フラップホ イール，バフなどの接触面積の大きな弾性研磨工具を使用す ることで，パイプ長手方向と平行に研磨工具を押し付けてへ アーライン状研磨目を入れる縦目研磨も行われている。

(5) 研磨ロボット

今後の研磨作業を維持, 発展させていくためには, 安全性, 作業環境の改善または研磨作業者の高齢化などの要因から， 研磨作業の省人化，ロボット化は大きなテーマになると思わ れる。一般的な研磨ロボットは, 加工物を把持する方式が多 く, この方式は大型部品の研磨には適さないが, 小型部品の

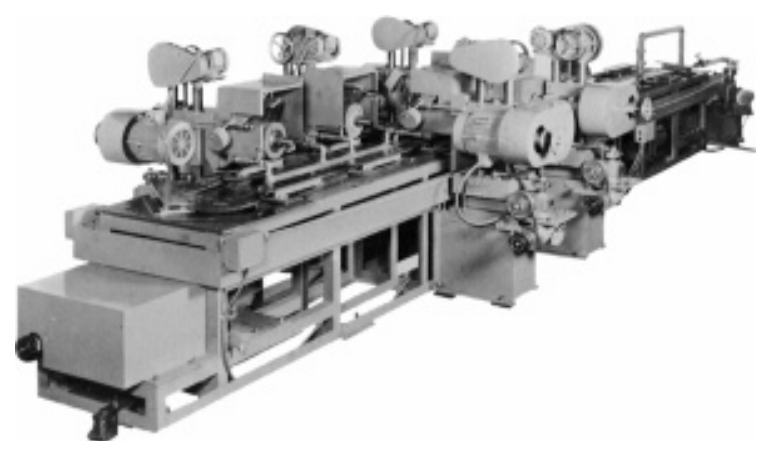

図 7 ストレート形研磨機() 


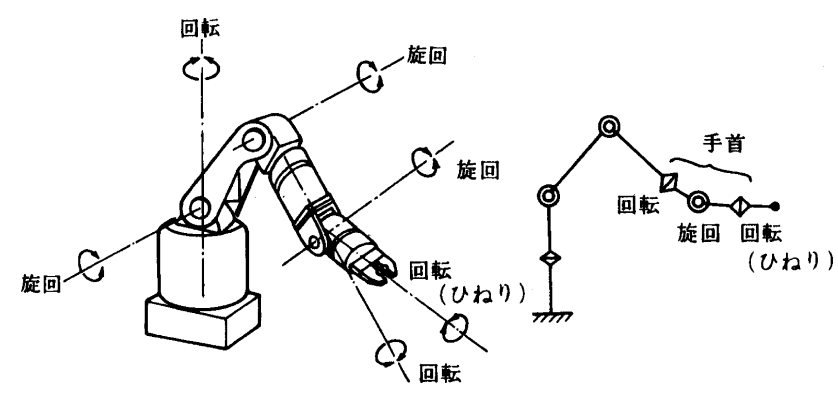

図 8 ロボット各軸の動作例5)

研磨においては人手作業の感覚をトレースするには適してい る。汎用自動研磨機と同様に複数台の研磨工具ヘッドを設置 することによって, 粗磨きから仕上げ研磨までを 1 台の研磨 ロボットで加工できる。

大型部品の研磨またはばり取りなどの特殊な研磨は, 研磨 工具把持方式が多く, この方式では基本的に 1 種類の研磨工 具を把持し加工するが, 最近ではオートツールチェンジャに よって複数の工具を使用することもできるようになっている。 適用される主な研磨品としては，水栓金具，ドアハンドルな どの複雑形状部品または自動車バンパ，ドアモールなどの大 型部品などの研磨である

研磨ロボットでの研磨加工において, ロボットの姿勢制御, 可搬重量, 位置決め精度などの機能として, 次のような特性 が必要とされている。

自由度：独立に制御可能な軸数を示している。曲面部品を 人手作業と同じように全面を研磨するには，6自由度が必要 とされている。

可搬重量 : 手首, 関節部などの許容トルクを複合した動作 時の最大荷重を示している。研磨時の荷重としては，30～50 $\mathrm{N}$ 以上の押付荷重が必要であり, これに耐えられる剛性が 必要である。通常は, 加工物および治具重量と押付荷重を併 せて可搬重量 $300 \mathrm{~N}$ 以上の研磨ロボットが使われる。

負荷フィードバック：研磨時の押付荷重を一定または任意 に制御できる負荷フィードバック系が必要である。研磨部所
による押付荷重の変化または研磨工具の摩耗による押付荷重 の変化などを, 各種センサによってフィードバックして, 設 定された押付荷重に制御する方法である。図８にロボット各 軸の動作例5)を示す。

\section{3 集塵機}

研磨作業工場は，作業環境が污れる，または騒音などの発 生から一般的に良好な作業場とはいえない。最近の工場内で は，主に騒音対策から研磨機全体を囲う対策をし，同時に粉 塵の飛散を防止することが多い。さらに，作業環境の良好化 と同時に防災対策としても，適切な集塵装置を使用すること がより重要となってきている。特に，アルミニウム，チタン またはマグネシウムなどの材質の研磨を行う時には, 集塵機 として湿式の防爆タイプ仕様を使用するなど, 加工製品の材 質に応じた十分な配慮が必要である。

\section{5. 終わりに}

一般的な仕上げ研磨工具について説明したが, 現在の研磨 作業においては省力化，省人化と同時に，より良好な作業環 境を求める動きが加速している。研磨布工具およびバフなど は, 大量生産のスルーアウェイ工具として多量に使用されて きた。しかし, 最近の環境問題として, 使用後の研磨工具の 廃棄方法も大きな問題とされ, 研磨工具のあり方の, 見直し がせまられている。

研磨工具メーカとして, より広い視野に立った物作りが求 められていることを感じている。

\section{文献}

1) 研磨布紙加工研究会編; 実務のための新しい研磨技術, p. 62 （オーム社, 1992）.

精密工学会編; 新版精密工作便覧, p. 368 (コロナ社, 1992).

2 ) 精密工学会編; 新版精密工作便覧, p. 390 (コロナ社, 1992).

3 ）シケン; 総合カタログ, p. 8 (1993).

4 ）野水機械製作所；ストレートライン型自動研磨機械カタログ, p. 5 (1996).

5 ）労働省安全課; 産業用ロボット安全必携, p. 29（中央労働災 害防止協会, 1988). 